\title{
RESPONSE OF COTYLEDON EXPLANTS OF CAPSICUM ANNUUM L. CV. KUJAWIANKA TO CHOSEN PLANT GROWTH REGULATORS IN IN VITRO CULTURE
}

\author{
ALICJA FRAŚ, KRYSTYNA NOWAK \\ Department of Plant Anatomy and Cytology, Silesian University, \\ ul. Jagiellońska 28, 40-032 Katowice Poland
}

(Received: October 11, 1994. Accepted: February 18, 1995)

\begin{abstract}
Shoot buds originated directly on cotyledon explants of Capsicum annuum L. cv. Kujawianka, when Linsmaier \& Skoog medium was enriched with BAP $(2 \mathrm{mg} / \mathrm{l})$. Kinetin $(2 \mathrm{mg} / \mathrm{l})$ or kinetin with IAA $(1 \mathrm{mg} / \mathrm{l}+1 \mathrm{mg} / \mathrm{l})$ induced indirect shoot buds regeneration from callus. Rooting was obtained with explants cultivated on a medium containing NAA ( $0,5 \mathrm{mg} / \mathrm{l})$. Occurrence of the early stages of differentiation was proved at the histological level.
\end{abstract}

KEY WORDS: Capsicum annuum (L.) organogenesis, shoot buds, tracheary elements.

\section{INTRODUCTION}

Plant tissue culture in vitro is widely used for micropropagation of plants. Many plants of economic and horticultural value are propagated successfully using this technique.

Organogenesis in vitro is a complex and little understood process. Generally organogenesis is obtained from various explants via callus formation, but some are developing directly from the original explant cells. Direct differentiation of shoot buds has been observed in several plant species. In Solanum surratense shoot buds were formed on stem explants (Gupta and Chandra, 1982), while in Allium species (Rauber and Grunewaldt, 1988) and Myriophyllum heterophyllum (Kane and Albert, 1989) they formed on leaf explants. Shoot buds were induced directly on cotyledon explants of Albizia spp (Tomar and Gupta, 1988) and hypocotyl explants of Capsicum frutescens (Subhash and Christopher, 1988).

Capsicum annuum L., the red pepper, belongs to Solanaceae family. It is an important vegetable plant which has also medicinal value. The fruit of red pepper is rich in ascorbic acid, vitamins $\mathrm{B}_{1}, \mathrm{~B}_{2}, \mathrm{E}$, carotenoids, pro vitamin $\mathrm{A}$, organic acids (e.g. citric acid) and capsaicin. The application of in vitro techniques for the production of a large number of planthets of Capsicum annuum could be very important economically. Untill now the histological aspects of organogenesis in red pepper have been mentioned briefly (Agrawal et al., 1989), but without detailed description of the cellular events and the anatomical changes in the initial explants.

Our preliminary studies (data unpublished) allowed us to

establish the most efficient medium compositions for organogenesis on cotyledon explants of Capsicum annuum cv. Ku-

\section{Abbreviations:}

BAP, 6-benzylaminopurine; NAA, 2-naphthalene acetic acid; IAA, indole acetic acid. jawianka. The present work aimed at studying histological changes in the cotyledon explants and to observe sequence of the events leading to regeneration of the shoot buds.

\section{MATERIALS AND METHODS}

Seeds of Capsicum annuum L. cv. Kujawianka were obtained from the seed company Przedsiębiorstwo Nasiennictwa Ogrodniczego i Szkółkarstwa in Kraków. The seeds were soaked in tap water for 24 hours, surface-sterilized with aqueous $0.1 \% \mathrm{HgCl}_{2}$ for $5 \mathrm{~min}$ and then treated with $0.5 \%$ $\mathrm{H}_{2} \mathrm{SO}_{4}$ for 2 min. They were rinsed with distilled water (4 times $5 \mathrm{~min}$.) and then placed in culture tubes containing $5 \mathrm{ml}$ of $0.7 \%$ agar medium with $2 \%$ glucose. Germination took place in darkness.

Cotyledon explants from two-week-old seedlings were transferred onto the Linsmaier \& Skoog medium (1965), with their abaxial surfaces uppermost. The basal medium containing casein hydrolysate $(400 \mathrm{mg} / \mathrm{l})$, thiamine $(0.4 \mathrm{mg} / \mathrm{l})$ and meso-inositol $(100 \mathrm{mg} / \mathrm{l})$ was enriched with BAP, NAA, IAA and kinetin in various concentrations and combinations. The $\mathrm{pH}$ was adjusted to 5.8. The explants were cultured in a growth chamber at $25 \pm 2^{\circ} \mathrm{C}$ in continuous light (white, neutral fluorescent tubes; intensity ca. $1000 \mathrm{~lx}$ ) for four weeks.

For histological studies cotyledon explants were fixed in FAA (formaldehyde 5\%, acetic acid 5\%,70\% ethanol 90\%). at regular seven-day intervals. They were dehydrated through a graded series of ethanol and embedded in paraffin. Sections (about $15 \mu \mathrm{m}$ ) were stained with safranin and fast green and mounted in Canada balsam after dehydration.

\section{RESULTS}

Regeneration of shoot buds, almost $100 \%$, was obtained on media supplemented with $1 \mathrm{mg} / \mathrm{l} \mathrm{kinetin}$ and $1 \mathrm{mg} / \mathrm{l}$ of IAA or $2 \mathrm{mg} / \mathrm{l}$ BAP. The best regeneration of roots $(100 \%)$ was observed on a medium with $0.5 \mathrm{mg} / \mathrm{l} \mathrm{NAA}$. To compare the ef- 


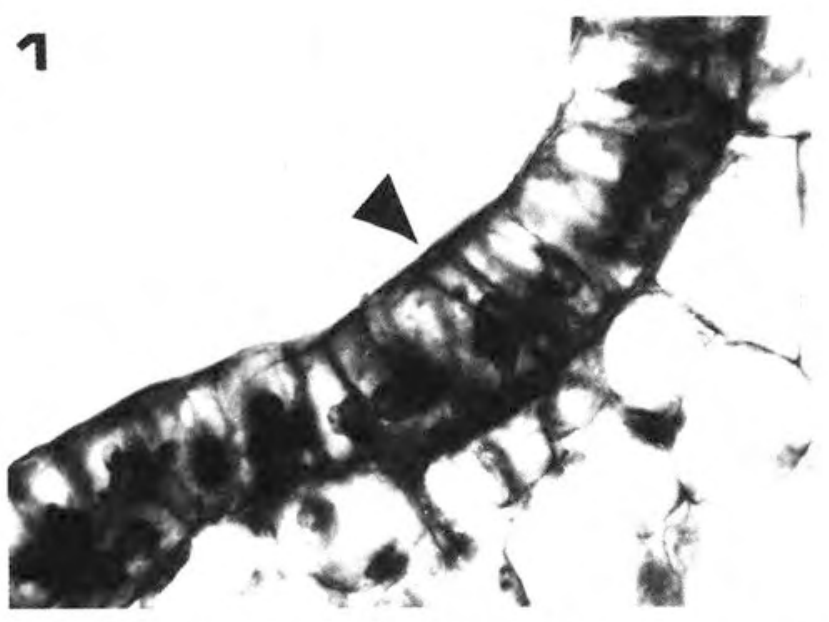

Fig. 1. Cotyledon explant cultured on Linsmaier \& Skoog medium with $2 \mathrm{mg} / \mathrm{l}$ BAP; longitudinal section; arrow indicates epidermis built of elongated cells with a large nucleus and dense cytoplasm; callus cells are visible beneath the epidermis, 800x.

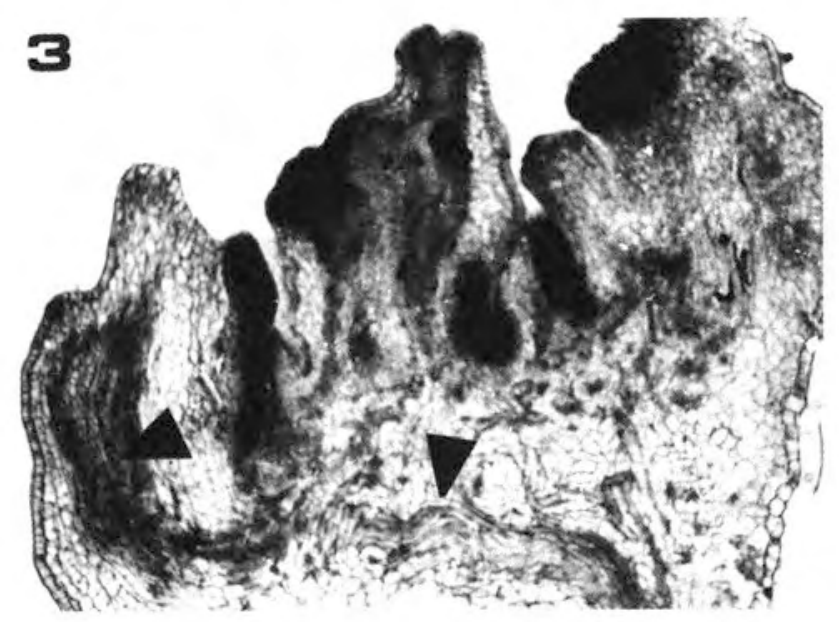

fects of two cytokinins, explants cultured on a medium with 2 $\mathrm{mg} / \mathrm{l}$ of kinetin were also analysed, though in this case shoot buds regeneration occurred with lower frequency.

Observations of several slides, made from explants fixed at regular intervals, allowed us to follow the histological changes during the formation of the leaves, roots and callus. In the first week of culture on a medium containing $2 \mathrm{mg} / \mathrm{l}$ BAP some increase of parenchymal cell was observed at the distal cut end of the explants and in contact with the medium surface some increase of parenchymal cells was observed. Accompanying frequent divisions of the epidermal cells were revealed by the presence of large nuclei, intensely stained with safranin (Fig. 1).

As a result of these divisions the epidermis folded. Both anticlinal and periclinal divisions were observed in the subepidermal layer. Parenchymal cells, adjoining the dividing cells, contained several starch grains (Fig. 2). Following all the changes, meristemoids formed and then gave rise to shoot buds and leaf primordia. After two weeks of culture, shoot buds and several large leaf primordia appeared (Fig. 3 and 4). Some of them had a large strand, consisting of tracheary elements with spiral wall thickenings. Groups of meristematic cells often occurred within the parenchyma of the explants (Fig. 7). After four weeks of culture, small quantities of callus and leaflets could be detected macroscopically on the distal end of the explant. On the proximal end there was only a

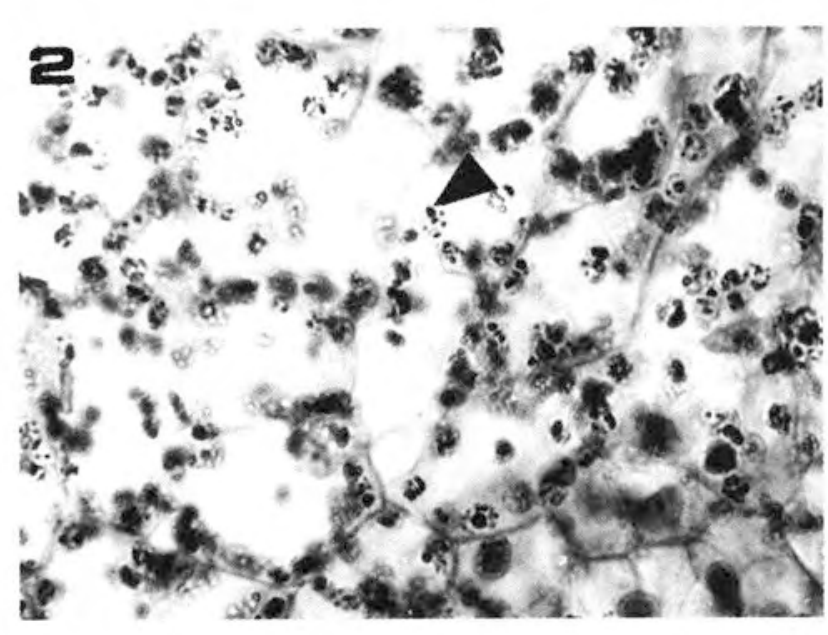

Fig. 2. Starch grains (indicated by arrow) in callus cells of the one-week-old cotyledon explant cultured on Linsmaier \& Skoog medium with $2 \mathrm{mg} / \mathrm{l} \mathrm{BAP,} 800 \mathrm{x}$.

Fig. 3. Early stages of shoot buds formation on cotyledon explants after two weeks of culture on Linsmaier \& Skoog medium with $2 \mathrm{mg} / \mathrm{l} \mathrm{BAP}$; large arrow indicates a vascular bundle of a regenerated leaf, callus can be seen beneath the regenerated structures, $125 \mathrm{x}$.

small volume of callus, formed as early as the first week of culture.

Some of the epidermal cells divided after one week of culture, differentiated glandular hairs. After two weeks of culture, the hairs were already fully developed.These hairs were composed of a short one-, or two-celled stalk and multicellular spherical head. They appeared on the whole epidermal surface covering newly regenerated structures (Fig. 8).

Divisions of the parenchyma and callus cells in the region between the regenerated shoot buds and the cotyledon explant led to the formation of elongated cells with large nuclei, distinctly different from the neighbouring cells. These cells were arranged in strands running from the explant vascular bundle towards the forming shoot buds (Fig. 9). Then the cells differentiated into tracheary elements with spiral wall thickenings, identical to those in the vascular bundle of the explant. These elements were a continuation of the vascular tissue of the explant in the direction of shoot buds. Differentiation of the vascular tissue within the forming leaf primordia occured basally, while the vascular bundle of the explant elongated into the apical direction. This mode of joining the vascular tissue of the explant and the leaf primordia resembles the differentiation pattern of the shoot vascular system in vivo.

Apart from the differentiating vascular tissue, connecting shoot buds to the explant, tracheary elements were observed, single or in groups. The tracheary elements differentiated also 


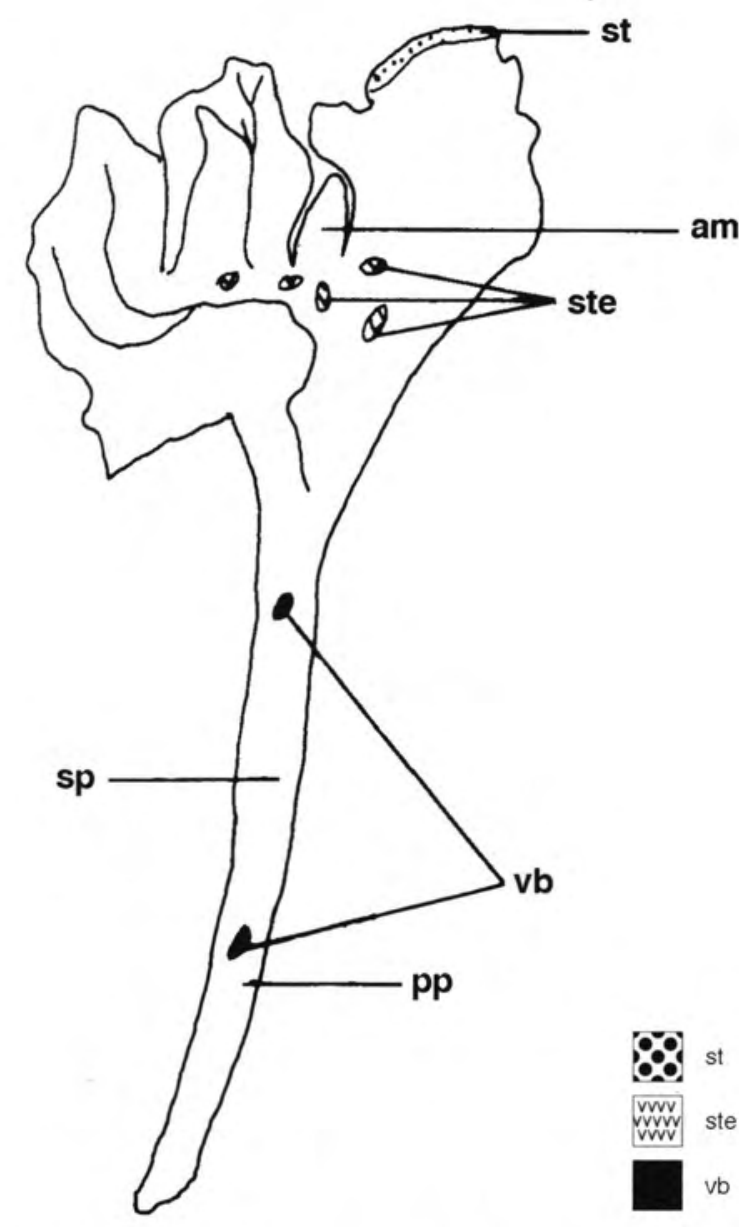

Fig 4. Longitudinal section through the leaf explant fixed after two weeks of culture on a basal medium supplemented with $2 \mathrm{mg} / \mathrm{l} \mathrm{BAP}$, $12 \mathrm{x}$ Explanations:

am - apical meristem

pp - palisade parenchyma

sp - spongy parenchyma

st - scar tissue

ste - tracheary elements with spiral wall thickenings

$\mathrm{vb}$ - vascular bundle of the cotyledon explant.

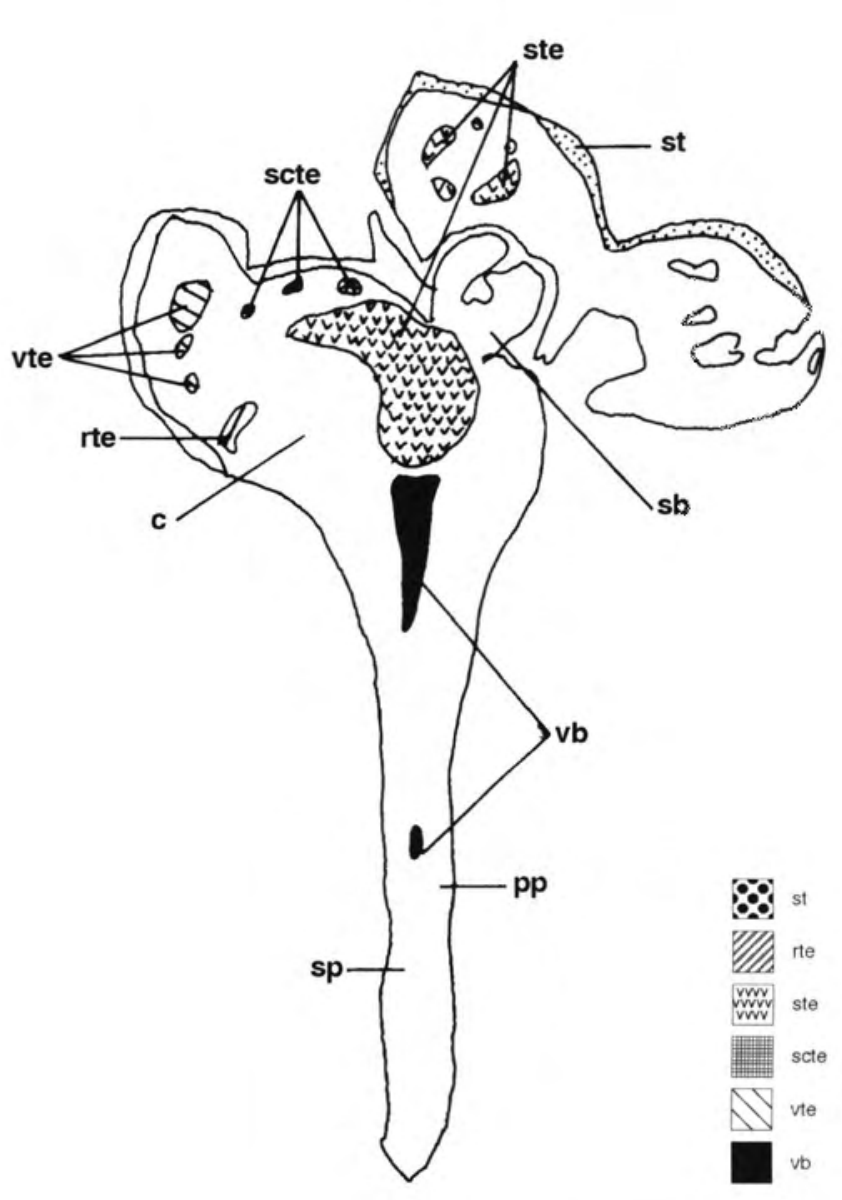

Fig 5. Longitudinal section through the leaf explant fixed after four weeks of culture on a basal medium supplemented with $1 \mathrm{mg} / \mathrm{l}$ kinetin $+1 \mathrm{mg} / \mathrm{l}$ IAA, $12 \mathrm{x}$

Explanations:

c - callus

sb - shoot buds

pp - palisade parenchyma

sp - spongy parenchyma

st - scar tissue

rte - tracheary elements with reticulate wall thickenings

ste - tracheary elements with spiral wall thickenings

scte - tracheary elements with scalariform wall thickenings

vte - tracheary elements with various wall thickenings: spiral, reticulate, scalariform and pitted

vb - vascular bundle of the cotyledon explant.

ranged in periclinal rows were frequently observed on the callus surface. The whole pattern resembled the periderm (Fig. $15)$.

Several tracheary elements, differentiating from the elongated cells, were arranged in rows and whirls located among the callus cells. These elements were irregularly shaped and the structure of their secondary wall varied considerably regarding its pattern. Elements with spiral, reticulate, scalariform and pitted type of secondary wall thickenings were found (Fig. 13). All tracheary elements were strongly thickened and lignified, and their average length was $30.9 \mu \mathrm{m}$. After four weeks of culture, rosettes of leaves could be observed (Fig. 16).

Regeneration of shoot buds from the explants cultured on the medium with $2 \mathrm{mg} / \mathrm{l}$ kinetin occurred indirectly (Fig.6), via callus, similarly to the regeneration under the influence of kinetin together with IAA (see above). Histological analysis 


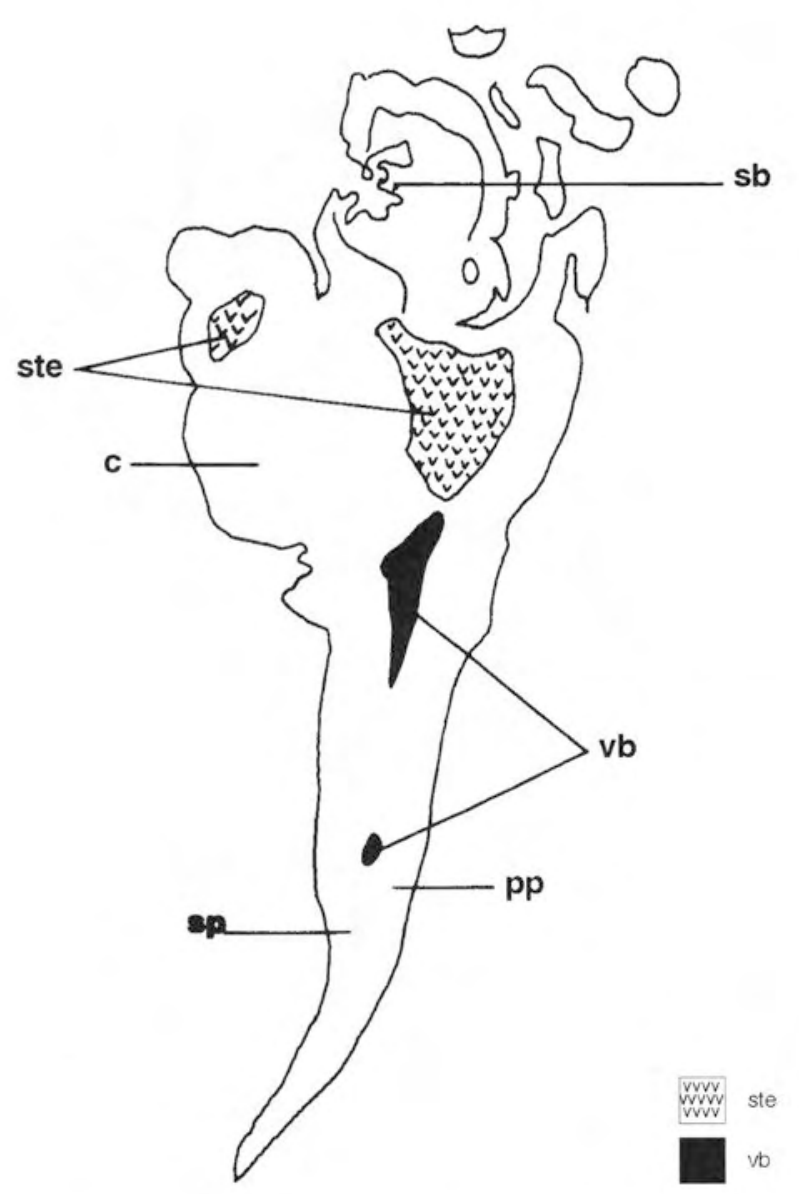

Fig 6. Longitudinal section through the leaf explant fixed after four weeks of culture on a basal medium supplemented with $2 \mathrm{mg} / \mathrm{l}$ kinetin, $12 \mathrm{x}$

Explanation:

c - callus

sb - shoot buds

pp - palisade parenchyma

sp - spongy parenchyma

ste - tracheary elements with spiral wall thickenings

vb - vascular bundle of the cotyledon explant..

revealed that the callus cells located in the vicinity of the regenerated structures contained several starch grains. The surface of the shoot buds was covered by an epidermis with hairs composed of multicellular head and pedicle. Tracheary elements with spiral wall thickenings, elongated $(54.8 \mu \mathrm{m})$ and slightly lignified, were observed in the callus (Fig. 14).

Histological analysis of the explants, cultured on medium with $0,5 \mathrm{mg} / \mathrm{l} \mathrm{NAA}$, indicated that roots differentiated both directly from explant tissues (Fig. 17) or via the callus tissue (Fig. 18). In both cases rhizogenesis occurred adjacently to the tracheary elements.

\section{DISCUSSION}

The anatomical studies proved that two cytokinins, applied in equal concentrations, stimulated the process of shoot bud regeneration in two ways. In the presence of BAP, the shoot buds formed directly from the explant tissues, in the primary phase of the culture. These results are compatible with the findings of Agrawal et al. (1989). Kinetin induced at first callus formation, then shoot buds differentiated from the callus.

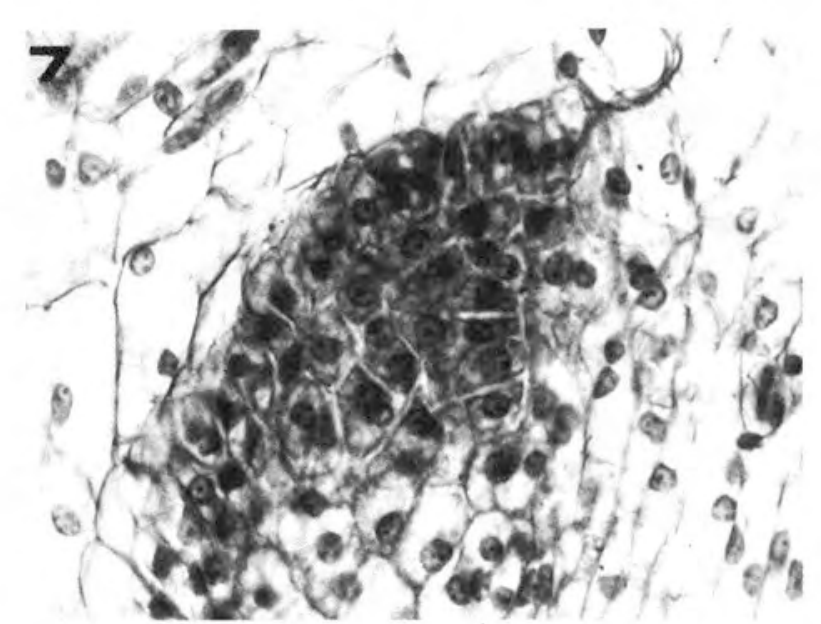

Fig. 7. Centres of meristematic cells forming in the callus tissue of a two-week-old cotyledon explant, cultured on Linsmaier \& Skoog medium with $2 \mathrm{mg} / \mathrm{l} \mathrm{BAP,} 800 \mathrm{x}$.

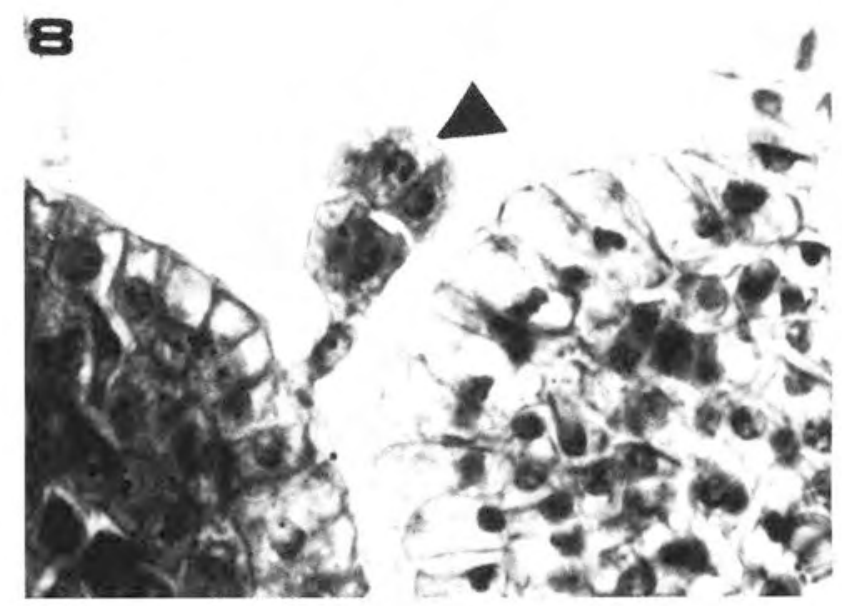

Fig. 8. Glandular hair (indicated by arrow) growing out of an epidermis covering a shoot bud formed on a two-week-old cotyledon explant cultivated on Linsmaier \& Skoog medium with 2mg/l BAP, 800x.

Addition of auxin (IAA) to the media containing kinetin caused some increase in the indirect regeneration of the shoot buds. Indirect shoot buds regeneration appeared only in the final phase of culturing, what may be explained as acquiring by callus the capacity to regenerate during the culture period (Barciela, Vietez, 1991). According to the previous studies on red pepper, carried out by Ochoa and Garcia (1990), the process of rhizogenesis is stimulated mainly by auxins. Our studies confirm these observations.

Several hairs, composed of multicellular head and pedicle, were observed on shoot buds and leaves regenerated on media containing cytokinins. They were similar to the glandular hairs covering the stems and the abaxial leaf surface of plant in vivo (Somos, 1984). It may be assumed that the cytokinins which initiated multiple divisions within the epidermal layer at the beginning of the culture period, also induced divisions in the epidermal layer, giving rise to these hairs.

Tracheary elements in the callus always differentiated from elongated cells. It seems interesting that these elongated cells were arranged in single rows or whirls. 


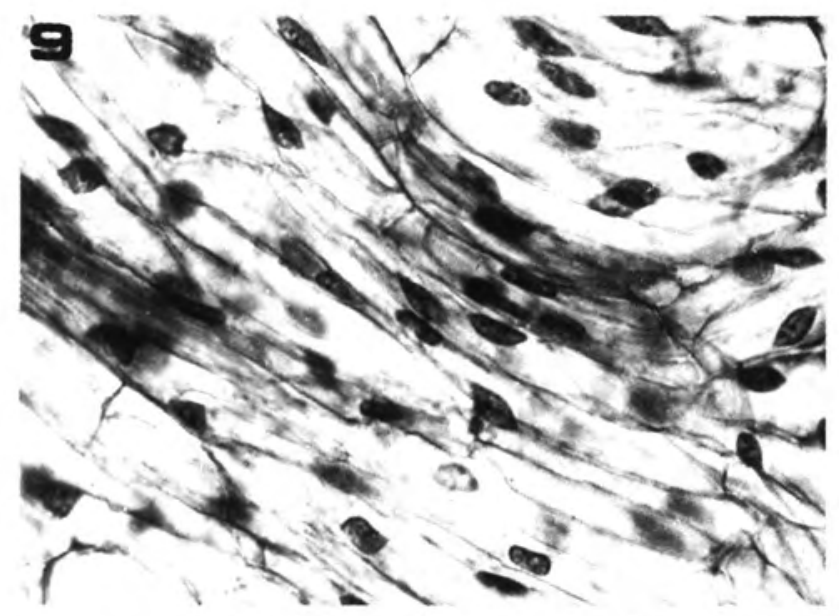

Fig. 9. Strands of elongated cells in callus of the cotyledon explant after two weeks of culture on Linsmaier \& Skoog medium with $2 \mathrm{mg} / \mathrm{l}$ BAP. The strands join the explant vascular bundle and elongate towards the leaf vascular bundle, $800 x$.

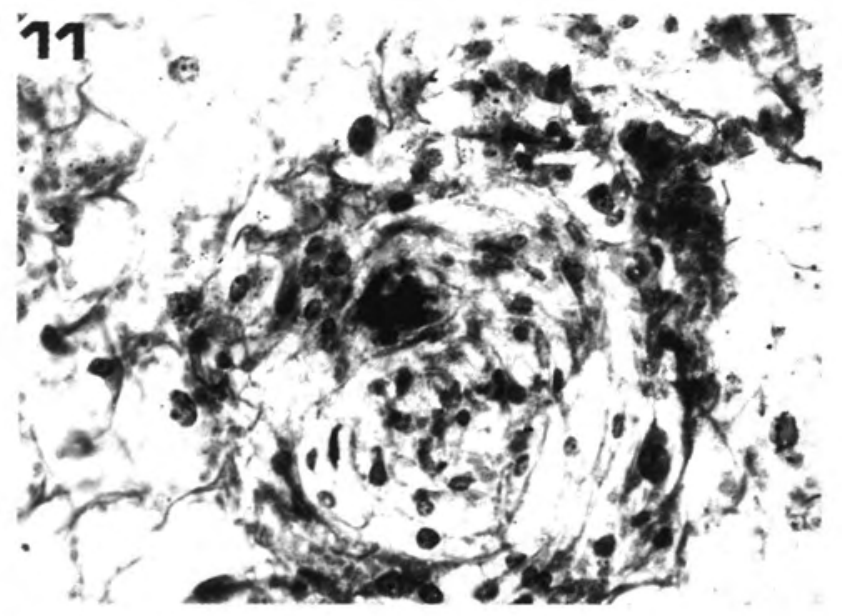

Fig. 11. Whirls of elongated cells in the callus of a hypocotyl explant cultured on Linsmaier \& Skoog medium with $2 \mathrm{mg} / \mathrm{l}$ BAP, 320x.

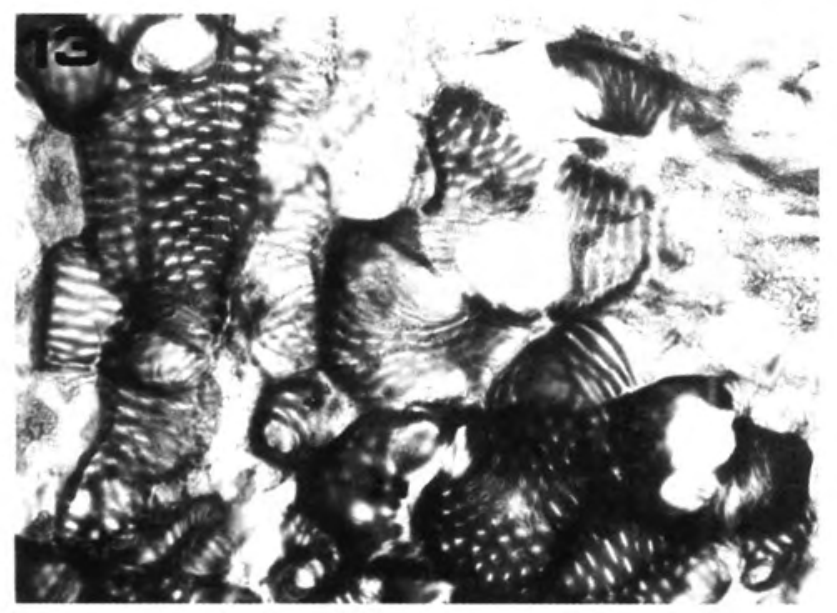

Fig. 13. Tracheary elements within the callus of four-week-old cotyledon explant; basal medium with $1 \mathrm{mg} / \mathrm{l}$ kinetin and $1 \mathrm{mg} / \mathrm{l}$ IAA, tracheary elements with various wall thickenings: $\mathrm{S}$ spiral, Sc - scalariform, R - reticulate, P - pitted. Note that the tracheary elements lie in different planes within a group, $800 \mathrm{x}$.

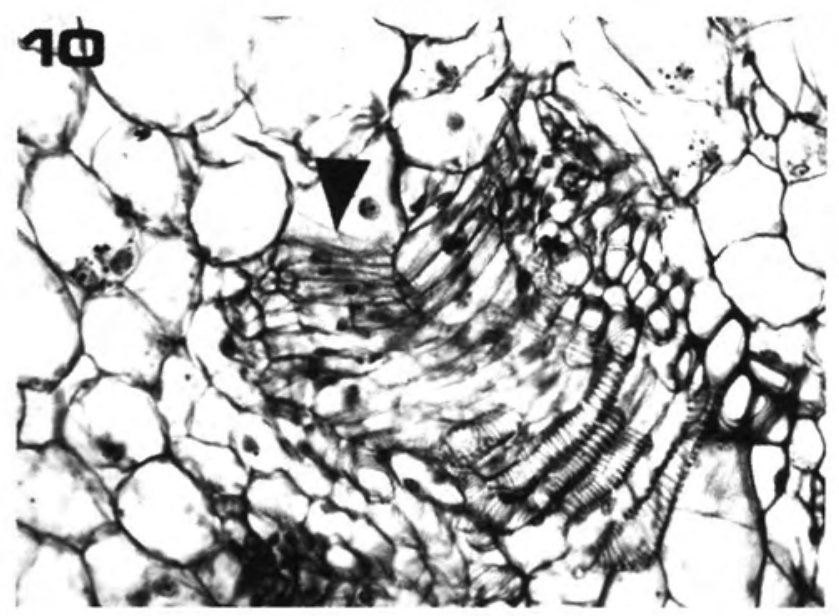

Fig. 10. Elongated cells (indicated by arrow) arranged in strands running through the callus of the cotyledon explant, cultured on Linsmaier \& Skoog medium with $2 \mathrm{mg} / \mathrm{l}$ BAP; differentiating tracheary elements are clearly visible, $320 x$.

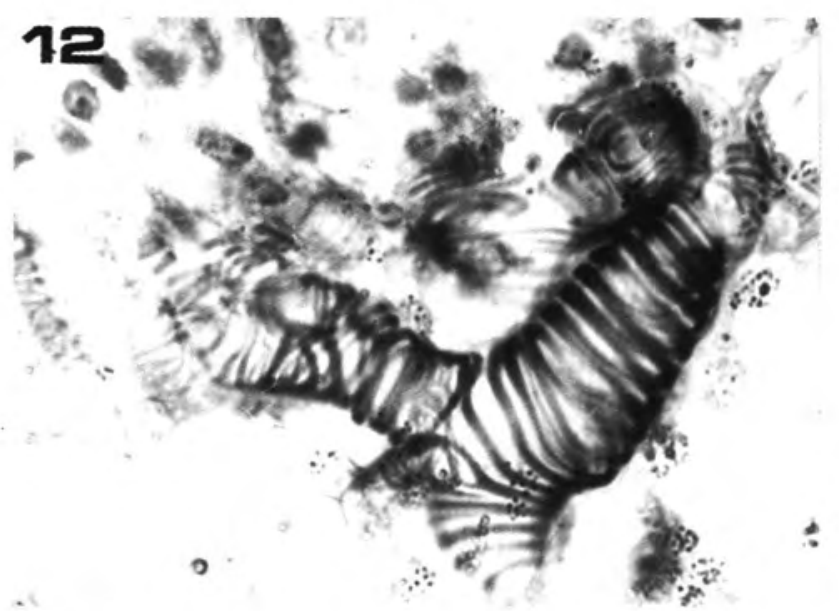

Fig. 12. Tracheary elements with spiral wall thickenings within the callus of the cotyledon explant cultured on Linsmaier \& Skoog medium with various growth regulators; two-week-old explant, basal medium with $2 \mathrm{mg} / \mathrm{l}$ BAP, tracheary elements with spiral wall thickenings, $800 x$.

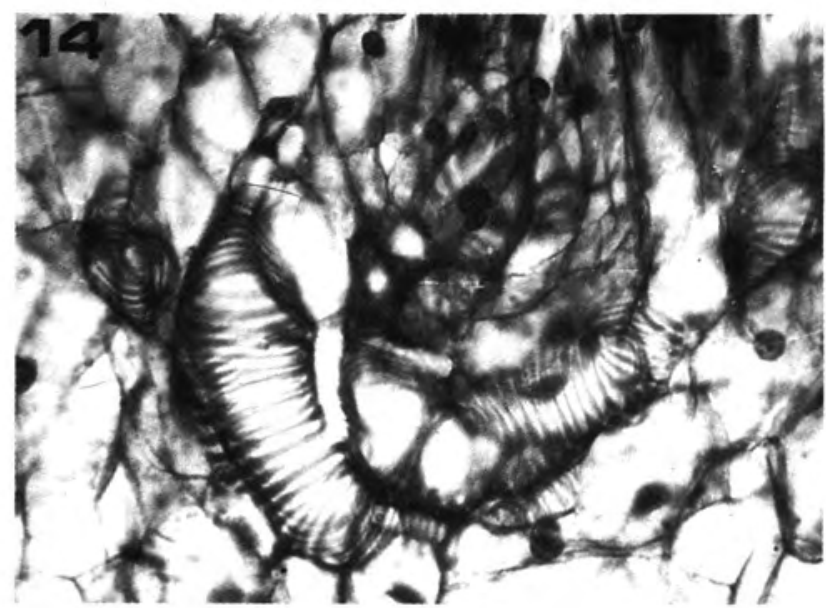

Fig. 14. Tracheary elements with spiral wall thickenings within the callus of the two-week-old cotyledon explant; basal medium with $2 \mathrm{mg} / \mathrm{l}$ kinetin, $800 \mathrm{x}$. 


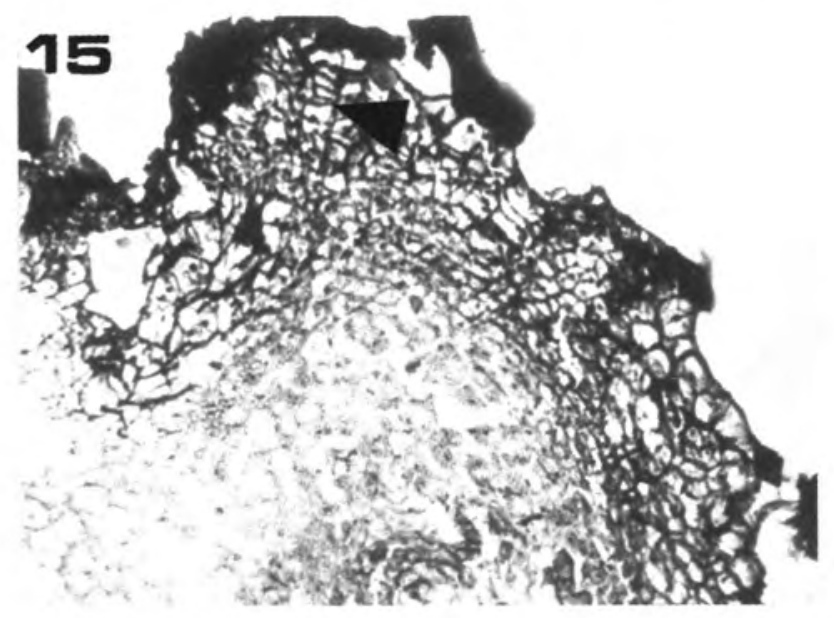

Fig. 15. Scar tissue at the cut end of a cotyledon explant cultured on Linsmaier \& Skoog medium with $1 \mathrm{mg} / \mathrm{l}$ IAA and $1 \mathrm{mg} / \mathrm{l}$ kinetin. The cells are arranged in periclinal rows, resembling the periderm (arrow), 125x.

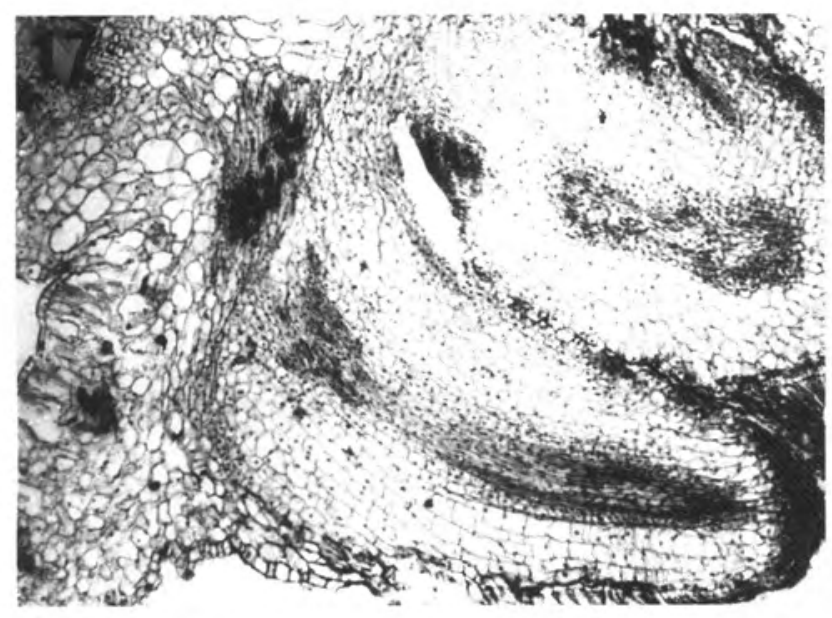

Fig. 17. Direct regeneration of roots on a cotyledon explant cultured on Linsmaier \& Skoog medium with $0.5 \mathrm{mg} / \mathrm{l}$ NAA. Roots regenerate directly from explants in the vicinity of the vascular bundle, $125 \mathrm{x}$.

Kurczyńska (1986) observed similar whirls of cambial cells, covering the stem of Fraxinus excelsior, near the adventitious buds. She interpreted this arrangement on the basis of the circular flux of auxin.

The requirement of initial cell divisions for the differentiation of tracheary elements is still an open question. Fukuda and Komamine (1980) reported that during the culture of Zinnia leaf mesophyl (the system of isolated cells) cell divisions were not a prerequisite for tracheary elements formation. However, Phillips (1987) pointed out that in the culture of explants from tubers of Helianthus tuberosus (multicellular system) cell divisions were necessary for the differentiation of tracheary elements. Our studies, carried out on the multicellular system, provide evidence for the latter hypothesis.

Our results show that the combination of auxin and cytokinin caused formation of smaller tracheary elements than cytokinin alone. Aloni (1992) concluded that in vivo high levels of auxins in the stem close to the young leaves induced several small vessels, though with a lower concentration of auxins differentiation occurred more slowly and there were fewer and larger vessels.

\section{6}

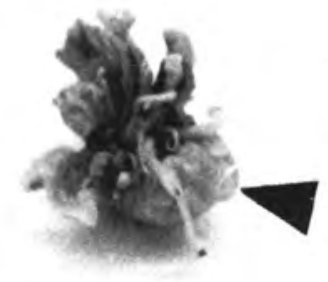

Fig. 16. Rosette of young leaves growing out of the explant cultured on Linsmaier \& Skoog medium containing $1 \mathrm{mg} / \mathrm{l} \mathrm{IAA} \mathrm{+} 1$ $\mathrm{mg} / \mathrm{l}$ NAA. Arrow indicates callus tissue, $2 \mathrm{x}$.

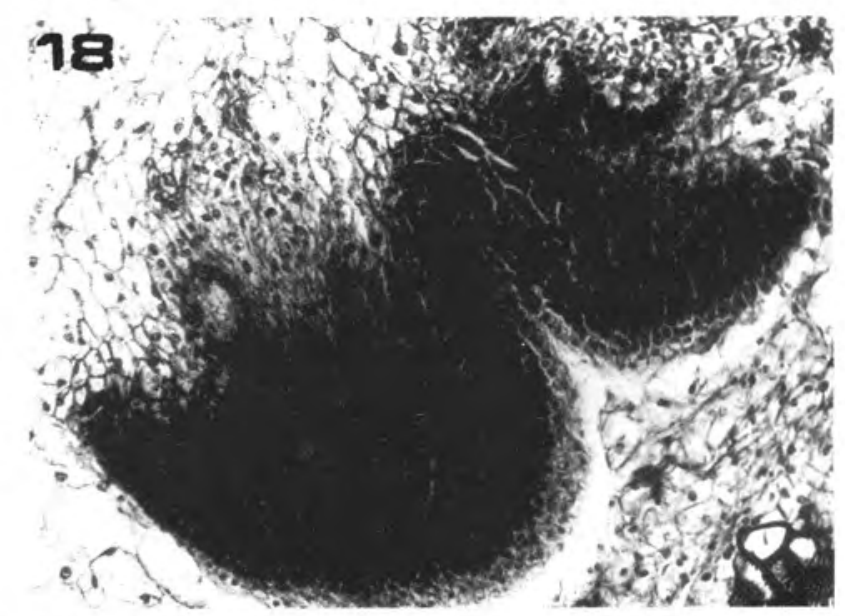

Fig. 18. Indirect regeneration of roots on a cotyledon explant cultured on Linsmaier \& Skoog medium with $0.5 \mathrm{mg} / \mathrm{l}$ NAA. Roots regenerate indirectly from callus tissue, $320 x$.

\section{LITERATURE CITED}

AGRAWAL S., CHANDRA N., KOTHARI S.L., 1989. Plant regeneration in tissue cultures of pepper (Capsicum annuum L. cv mathania). Plant Cell, Tissue and Organ Culture 16: 47-55.

ALONI R., 1992. The control of vascular differentiation. Int. J. Plant Sci. 153: S90-S92.

BARCIELA J., VIEITEZ A.M., 1993. Anatomical sequence and morphometric analysis during somatic embryogenesis on cultured cotyledon explants of Camellia japonica L. Annals of Botany 71: 395-404.

FUKUDA.H., KOMAMINE.A., 1980. Establishment of an experimental system for the study of tracheary element differentiation from single cells isolated from the mesophyll of Zinnia elegans. Plant Physiol. 65: 57-60

GAMBORG O.L., MURASHIGE T., THORPE T.A., VASIL I.K., 1976. Plant tissue culture media. In vitro 12: 473-478.

GUPTA S.C., CHANDRA N., 1982. Control of organogenesis in cultures of leaf, multi- layered strips and segments of stem and root in Solanum surrattense Burn. Indian J. Exp. Biol. 20: 126-131.

KANE M.E., ALBERT L.S., 1989. Comparative shoot and root regeneration from juvenile and adult aerial leaf explants of variable-leaf milfoil. J. Aquat. Plant Manage. 27: 1-10. 
KURCZYŃSKA E.U., 1986. Terminal vessel and early vessel arrangement in internodes of Fraxinus excelsior. Acta Soc. Bot. Pol. 55: 3-10.

LINSMAIER E.M., SKOOG F. 1965. Organic growth factor requirements of tobacco tissue culture. Physiologia Plantarum 18: 100-126.

OCHOA-ALEJO N., GARCIA-BAUTISTA M.A.R. 1990. Morphogenetic responses in vitro of hypocotyl tissues of chili pepper (Capsicum annuum L.) to growth regulators. Turrialba 40: 311-318.

PHILLIPS.R., 1987. Effects of sequential exposure to auxin and cytokinin on xylogenesis in cultured explants of Jerusalem artichoke (Helianthus tuberosus L.). Annals of Botany 59: 245-250.
RAUBER M., GRUNEWALDT J., 1988. In vitro regeneration in Allium species. Plant Cell Reports 7: 426-429.

SOMOS A., 1984. The paprika. Akademiai Kiado, Budapest, pp. 37-84.

SUBHASH K., CHRISTOPHER T., 1988. Direct plantlet formation in cotyledon cultures of Capsicum frutescens. Current Science 57: 99100.

TOMAR U.K., GUPTA S.C., 1988. In vitro plant regeneration of leguminous trees (Albizia spp). Plant Cell Reports 7: 385-388.

\section{REAKCJE EKSPLANTATÓW LIŚCIENIOWYCH CAPSICUM ANNUUM L. CV. KUJAWIANKA NA WYBRANE REGULATORY WZROSTU W KULTURZE IN VITRO}

\section{STRESZCZENIE}

Bezpośrednią regenerację pąków pędowych otrzymano z eksplantatów liścieniowych Capsicum annuum L. cv. Kujawianka, hodowanych na podłożu Linsmaier-Skooga z dodatkiem BAP $(2 \mathrm{mg} / \mathrm{l})$. Kinetyna $(2 \mathrm{mg} / \mathrm{l})$ lub kinetyna w kombinacji z IAA $(1 \mathrm{mg} / \mathrm{l}+1 \mathrm{mg} / \mathrm{l})$ indukowały pośrednią regenerację pąków pędowych. Ryzogenezę obserwowano na podłożu zawierającym NAA $(0,5 \mathrm{mg} / \mathrm{l})$. Procesy organogenezy badano na poziomie histologicznym.

SŁOWA KLUCZOWE: Capsicum annuum (L.), organogeneza, pąki pędowe, elementy trachealne. 